\title{
PENDUKUNG KEPUTUSAN PEMILIHAN SISWA TERBAIK PADA SMA CENDERAWASIH 2 DENGAN MENGGUNAKAN METODE SIMPLE ADDITIVE WEIGHTING BERBASIS WEB
}

\author{
Jerry Prabu Setya Adi ${ }^{1)}$ dan Windarto ${ }^{2)}$ \\ 1,2Teknik Informatika, Fakultas Teknologi Informasi, Universitas Budi Luhur \\ 1,2Jl. Raya Ciledug, Petukangan Utara, Kebayoran Lama, Jakarta Selatan 12260 \\ E-mail: Jerryprabu05@gmail.com¹),windarto@budiluhur.ac.id ${ }^{2)}$
}

\begin{abstract}
ABSTRAK
Pemilihan siswa terbaik di SMA Cendrawasih 2 Tangerang dilakukan disetiap tahun menjelang kenaikan kelas dengan kriteria-kriteria yang ditentukan oleh pihak sekolah. Sehingga siswa yang belajar, berpeluang sama untuk mendapatkan hadiah atau penghargaan atas pencapaian terbaiknya. Beberapa masalah ketika pemilihan siswa terbaik dilakukan, misalnya masih dilakukan dengan cara yang manual. Selain itu, kriteria yang dipakai dalam pemilihan siswa terbaik hanya satu. Hal ini memungkinkan terpilihnya siswa yang tertuju ke sasaran yang tidak akurat, dikarenakan nilai akhir satu siswa dengan siswa lainnya bisa dimungkinkan sama. Metode Simple Additive Weighting (SAW) ini dipilih karena dapat menentukan nilai bobot untuk setiap atribut, kemudian dilanjutkan dengan proses perankingan yang akan menyeleksi alternatif terbaik dari sejumlah alternatif yang ada. Dalam hal ini alternatif yang dimaksud adalah pemilihan siswa terbaik pada SMA Cenderawsih 2. Dengan metode perangkingan tersebut diharapkan penilaian akan lebih tepat karena didasarkan pada nilai kriteria dan bobot yang sudah ditentukan sehingga akan mendapatkan hasil yang lebih cepat, akurat dan objektif.
\end{abstract}

Kata Kunci: Pemilihan Siswa Terbaik, Simple Additive Weighting, Sistem Pendukung Keputusan

\section{PENDAHULUAN}

Menjadi siswa terbaik adalah impian dari setiap siswa yang ada di sekolah. Pemilihan siswa terbaik berdampak positif bagi budaya berprestasi serta menghargai prestasi siswa di sekolah dan secara langsung dan tidak langsung akan mengangkat martabat siswa dan sekolah tersebut.

Pemilihan siswa terbaik memang seharusnya ada di setiap sekolah khususnya SMA. Pemilihan siswa terbaik ini cocok dilakukan disetiap tahun menjelang kenaikan kelas dengan kriteria-kriteria yang ditentukan oleh pihak sekolah. Sehingga semua siswa yang belajar berpeluang sama untuk mendapatkan hadiah atau penghargaan atas pencapaian terbaiknya itu. Banyaknya siswa yang memiliki kemampuan yang berbeda-beda atau bahkan tidak jauh beda dengan siswa lainnya membuat hasil penilaian tidak jauh berbeda sehingga menimbulkan kesulitan untuk menentukan mana siswa yang terbaik.

Pada SMA Cenderawasih 2 Tangerang Selatan, ada beberapa masalah ketika pemilihan siswa terbaik dilakukan, misalnya pemilihan siswa terbaik masih menggunakan cara yang manual. Selain itu, kriteria yang dipakai dalam pemilihan siswa terbaik hanya satu yaitu rata-rata nilai rapot. Hal ini memungkinkan terpilihnya siswa yang tertuju ke sasaran yang tidak akurat, dikarenakan nilai akhir satu siswa dengan siswa lainnya bisa dimungkinkan sama sehingga pemilihan siswa terbaiknya tidak dengan kriteria yang ada.

Simple Additive Weighting (SAW) adalah mencari penjumlahan terbobot dari rating kinerja pada setiap alternatif pada semua atribut (Fishburn, 1967). Metode ini merupakan salah satu metode penyelesaian masalah Multi
Attribute Decision Making (MADM) yang paling sederhana dan paling banyak digunakan. Selain itu, metode ini juga merupakan metode yang paling mudah diaplikasikan, karena mempunyai algoritma yang tidak terlalu rumit. Metode Simple Additive Weighting (SAW) membutuhkan proses normalisasi matriks keputusan ke suatu skala yang dapat diperbandingkan dengan semua rating alternatif yang ada.

\section{RUANG LINGKUP}

Dari permasalahan tersebut, dibutuhkan suatu sistem pendukung keputusan yang dapat menentukan siswa terbaik dengan jumlah data yang banyak sehingga proses dalam mengolah data tersebut bisa lebih cepat dan tepat. Sistem tersebut menggunakan metode Simple Additive Weighting. Sistem ini nantinya akan digunakan menghitung dan mengurutkan nilai yang disebut perankingan. Kriteria-kriteria yang dipakai yaitu nilai akademik, kedisiplinan, absensi dan nilai non akademik dari tiap-tiap siswa SMA Cenderawasih 2.

\section{BAHAN DAN METODE}

Berikut disajikan kajian teori dan metodologi yang berkaitan dengan penelitian ini.

\subsection{Sistem Pendukung Keputusan}

Sistem pendukung keputusan (SPK) adalah sistem yang berbasis computer interaktif, yang membantu para pengambil keputusan untuk menggunakan data dan berbagai model untuk memecahkan masalah-masalah yang tidak terstuktur. 
Moore dan Chang mendefinisikan SPK sebagai sistem yang dapat diperluas untuk mampu mendukung analisis data dan permodelan keputusan, berorientasi terhadap perencanaan masa depan, dan digunakan pada interval yang tidak regular, dan tak terencana. Suatu sistem yang diperuntukan untuk membantu pembuat keputusan dalam kondisi keputusan yang kurang terstruktur atau semi terstruktur.

Sistem pendukung keputusan merupakan suatu sistem yang interaktif, yang dapat membantu pengambilan keputusan melalui penggunaan data dan model keputusan untuk memecahkan masalah. (Fitri and Nurhadi, 2017).

\subsection{Komponen Sistem Pendukung Keputusan}

Komponen sistem pendukung keputusan adalah sebagai berikut:

1. Data Management, termasuk database yang mengandung data yang relavan untuk berbagai situasi dan diatur oleh software yang disebut Data Base Management Systems (DBMS)

2. Model Management, melibatkan model finansial, statistical, management science, atau berbagai model kuantitatif lainnya. Sehingga dapat memberikan ke sistem suatu kemampuan analitis, dan manajemen software yang diperlukan.

3. Communication (dialog subsistem), user dapat berkomunikasi dan memberikan perintah pada DSS melalui subsistem ini. Ini berarti menyediakan antarmuka.

4. Knowledge Management, subsistem optional ini dapat mendukung subsistem lain atau bertindak sebagai komponen yang berdiri sendiri (Pratiwi, 2016).

Dibawah ini adalah model konseptual sistem pendukung keputusan:

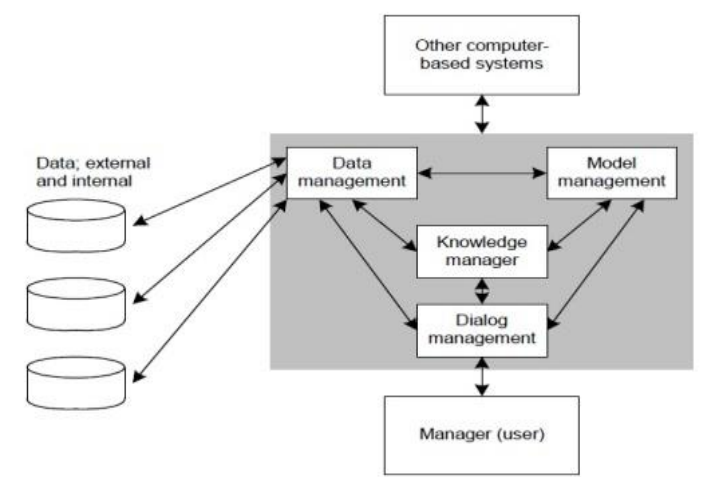

Gambar 1. Konseptual sistem pendukung keputusan (Pratiwi, 2016)

\subsection{Karakteristik Sistem Pendukung Keputusan}

Terdapat beberapa karakteristik dari sistem pendukung keputusan, yaitu:

1. Mendukung proses pengambilan keputusan suatu organisasi atau perusahaaan.

2. Adanya interface manusia atau mesin dimana manusia (user) tetap memegang kontrol proses suatu keputusan.
3. Mendukung pengambilan keputusan untuk membahas masalah terstruktur, semi terstruktur dan tidak terstruktur serta mendukung beberapa keputusan yang saling berinteraksi.

4. Memiliki kapasitas dialog untuk memperoleh informasi sesuai dengan kebutuhan.

5. Memiliki subsistem-subsistem yang terintegrasi sedemikian rupa sehingga dapat berfungsi sebagai kesatuan sistem.

6. Memiliki dua komponen utama yaitu data dan model.

\subsection{Keuntungan Sistem Pendukung Keputusan}

Sistem pendukung keputusan dapat memberikan keuntungan kepada pemakainya, yaitu:

1. Mampu mendukung pencarian solusi dari masalah yang kompleks.

2. Respon cepat pada situasi yang tidak diharapkan dalam kondisi yang berubah-ubah.

3. Meningkatkan kontrol manajemen dan kinerja.

4. Menghemat waktu dan biaya.

5. Keputusan yang diambil lebih tepat.

6. Meningkatkan produktivitas analisis.

\subsection{Simple Additive Weighting (SAW)}

Simple Additive Weighting adalah salah satu metode yang paling populer digunakan pada sistem pendukung keputusan, pemilihan kriteria untuk kasus yang akan diselesaikan dengan berbantuan sistem pendukung keputusan memerlukan penajaman yang berkaitan erat dengan masalah yang dihadapi. Hal-hal yang menjadi acuan untuk memilih kriteria hendaknya mempunyai urgensi kuat dengan masalah yang hendak dicari solusinya. Jumlah kriteria yang diambil untuk dianalisa tidak ada ketentuan yang pasti, namun semakin banyak variasi kriteria yang dipilih maka semakin bagus hasil yang didapatkan. Pada metode SAW, ada kriteria yang dipresepsikan sebagai kriteria benefit dan cost. Kategori kriteria benefit atau keuntungan, jika kriteria tersebut mempunyai nilai semakin besar maka semakin baik, sedangkan kriteria cost atau biaya semakin kecil nilainya maka semakin baik.

Metode Simple Additive Weighting sering juga dikenal dengan istilah metode penjumlahan berbobot. Konsep dasar metode Simple Additive Weighting adalah mencari penjumlahan terbobot dari rating kinerja pada setiap alternatif pada semua atribut. Metode Simple Additive Weighting disarankan untuk menyelesaikan masalah penyeleksian dalam sistem pengambilan keputusan multi proses. Metode Simple Additive Weighting merupakan metode yang banyak digunakan dalam pengambilan keputusan yang memiliki banyak atribut. Metode Simple Additive Weighting membutuhkan proses normalisasi matriks keputusan (x) ke suatu skala yang dapat diperbandingkan dengan semua rating alternatif yang ada (Situmorang, 2015).

Rumus dari metode simple additive weighting adalah sebagai berikut (1) (2) 


$$
\begin{aligned}
& r_{i j}=\int \frac{X_{i j}}{\operatorname{Max}_{i} X_{i j}} \text { Jika j adalah atribut benefit } \\
& r_{i j}=\int \frac{\operatorname{Min}_{i} X_{i j}}{X_{i j}} \text { Jika j adalah atribut cost }
\end{aligned}
$$

Keterangan (1)(2)

$\mathrm{Rij} \quad=$ nilai rating kinerja ternormalisasi

$\mathrm{Xij}=$ nilai atribut yang dimiliki dari setiap kriteria

Max Xij = nilai terbesar dari setiap kriteria

Min Xij = nilai terkecil dari setiap kriteria

Benefit $=$ jika nilai terbesar adalah terbaik

cost $=$ jika nilai terkecil adalah terbaik

dimana rij sebagai rating kinerja ternormalisasi dari alternatif Ai pada atribut $\mathrm{Cj} ; \mathrm{I}=1,2, \ldots, \mathrm{m}$ dan $\mathrm{j}=1,2$, $\ldots, n$. Nilai preferensi untuk setiap alternatif ( Vi ) dapat dilihat pada (3)

$$
V_{1}=\sum_{j=1}^{n} W_{j} r_{i j}
$$

Keterangan (3)

$\mathrm{V}_{\mathrm{i}} \quad=$ ranking untuk setiap alternatif

$\mathrm{W}_{\mathrm{j}} \quad=$ nilai bobot dari setiap kriteria

$\mathrm{r}_{\mathrm{ij}} \quad=$ nilai rating kinerja ternormalisasi

Nilai Vi yang lebih besar mengindikasikan bahwa alternatif Ai lebih terpilih.

\subsection{Langkah-langkah Penyelesaian Metode SAW}

Langkah-langkah penyelesaian dalam menggunakan metode simple additive weighting, yaitu:

1. Menentukan kriteria-kriteria yang akan dijadikan acuan dalam pengambilan keputusan, yaitu $\mathrm{Ci}$.

2. Menentukan rating kecocokan setiap alternatif pada setiap kriteria.

3. Membuat matriks keputusan berdasarkan kriteria (Ci), kemudian melakukan normalisasi matriks berdasarkan persamaan yang disesuaikan dengan jenis atribut (keuntungan ataupun atribut biaya) sehingga diperoleh matriks ternomalisasi R.

4. Hasil akhir diperoleh dari proses perangkingan yaitu penjumlahan dari perkalian matriks ternormalisasi $\mathrm{R}$ dengan vektor bobot sehingga diperoleh nilai terbesar yang dipilih sebagai alternatif terbaik (Ai) sebagai solusi.

\subsection{Kelebihan Metode SAW}

Berikut ini adalah beberapa kelebihan yang dimiliki oleh metode SAW yaitu:

1. Mengumpulkan data kriteria untuk menentukan nilai bobot pada setiap kriteria.

2. Menentukan atribut kriteria memilih perhitungan yang digunakan dalam proses normalisasi.

3. Kemudian merubah data menjadi bobot himpunan agar dapat dilakukan perhitungan normalisasi.
4. Setelah dilakukan perhitungan normalisasi, dilanjutkan dengan proses perangkingan yang akan menyeleksi alternatif terbaik dari sejumlah alternatif.

5. Penilaian akan lebih tepat karena didasarkan pada nilai kriteria dan bobot preferensi yang sudah ditentukan.

\subsection{Kekurangan Metode SAW}

Terdapat pula beberapa kekurangan yang dimiliki oleh metode SAW, yaitu:

1. Digunakan pembobotan lokal.

2. Perhitungan dilakukan dengan menggunakan nilai secara manual.

3. Adanya perbedaan perhitungan normalisasi matriks sesuai dengan nilai atribut (antara lain nilai benefit dan cost).

\subsection{Pengertian Siswa Terbaik}

Siswa terbaik adalah siswa yang berprestasi dalam melaksanakan tugasnya selama periode tertentu sesuai standar kompetensi dan kriteria yang telah ditetapkan. Siswa terbaik juga selalu mengikuti aturan-aturan yang telah ditetapkan oleh sekolah atau guru yang mendidiknya.

Ada beberapa hal yang harus diperhatikan dalam menyusun standar penilaian siswa terbaik yang baik dan benar, yaitu:

1. Validity adalah keabsahan standar sesuai dengan kriteria yang dinilai. Keabsahan yang dimaksud adalah standar tersebut memang benar-benar sesuai dengan kewajiban siswa untuk menjalankannya.

2. Agreement yaitu standar penilaian tersebut disetujui dan diterima oleh semua siswa yang akan mendapat penilaian.

3. Realism berarti standar penilaian tersebut bersifat realistis, dapat dicapai oleh seluruh siswa dan sesuai dengan kemampuan siswa.

4. Objectivity berarti standar penilaiannya harus bersifat obyektif yaitu adil, mampu mencerminkan keadaan yang sebenarnya tanpa menambah atau mengurangi kenyataan dan sulit untuk dipengaruhi oleh bias-bias penilaian.

\subsection{Arsitektur Program}

Arsitektur program adalah suatu proses tahapan berupa gambaran secara singkat mengenai program yang akan dibuat, dimana yang pertama kali akan diproses adalah penentuan kriteria, nilai kriteria dan nilai alternatif. Kriteria adalah suatu obyek ya menentukan poin-poin penilaian dari sekolah, dimana poin-poin ini yang memegang proses penting dari inti sistem yang akan dibuat. Kemudian bobot dari suatu kriteria ditentukan oleh pihak sekolah atas kesepakatan bersama. Berikut pada gambar 2 adalah gambaran dari sistem pendukung keputusan ini. 


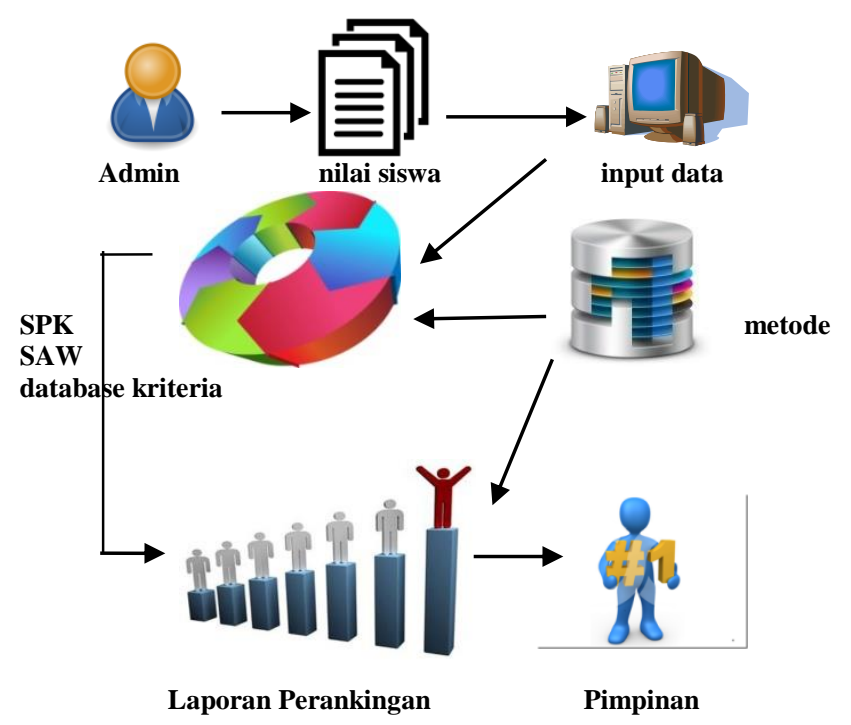

Gambar 2. Arsitektur Program

\subsection{Penerapan Algortima SPK dengan Metode} SAW

Terdapat 4 langkah untuk melakukan perhitungan pemilihan siswa terbaik menggunakan metode Simple Additive Weighting, yaitu:
1. Menentukan kriteria yang akan dijadikan acuan dalam pengambilan keputusan $(\mathrm{Ci})$

2. Membuat atau mencocokan antara alternatif dengan setiap kriteria

3. Membuat matriks keputusan berdasarkan allternatif dengan kriteria yang sudah diisi, lalu melakukan normalisasi matriks sehingga mendapatkan matriks ternomalisasi.

4. Hasil akhir diperoleh dari proses perankingan yaitu penjumlahan dari perkalian matriks ternormalisasikan $\mathrm{R}$ dengan vektor bobot sehingga diperoleh nilai terbesar yang dipilih sebagai alternatif terbaik (Ai) sebagai solusi.

\subsection{Rancangan Basis Data}

Dalam pembuatan aplikasi pemilihan siswa terbaik, digunakan sebuah database yang terdapat rancangan ERD, LRS dan spesifikasi basis data yang digunakan yaitu:

\section{Entity Relationship Diagram (ERD)}

Entity relationship diagram berisi komponenkomponen himpunan entitas dan himpunan relasi. Masing masing dilengkapi dengan atribut yang mewakili seluruh data yang ada. ERD dibuat untuk menggambarkan suatu database dengan diagram yang sederhana. Berikut gambar 3 adalah ERD dari pemilihan siswa terbaik.

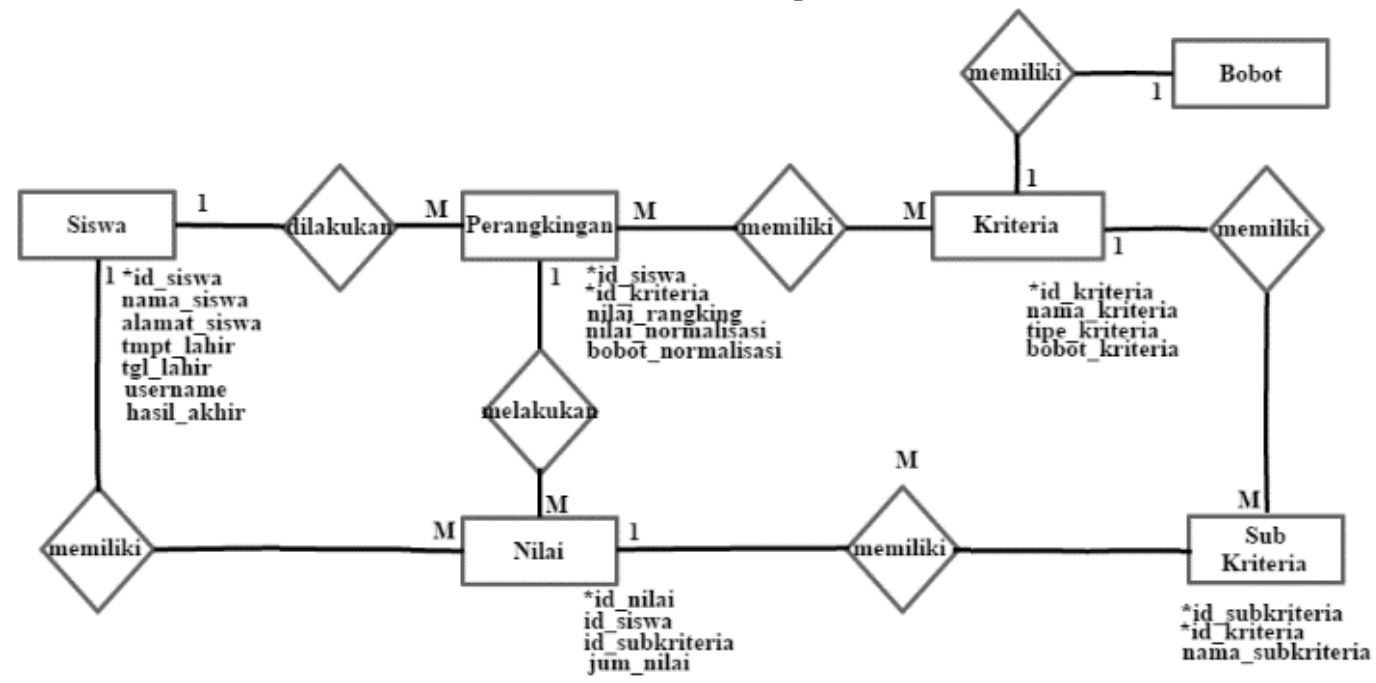

Gambar 3. Entity Relationship Diagram (ERD)

2. Logical Relational Structure (LRS)

Logical Relational Structure adalah representasi dari struktur record-record pada tabel yang terbentuk dari hasil antar himpunan entitas. Berikut pada gambar 4 adalah LRS dari pemilihan siswa terbaik. 


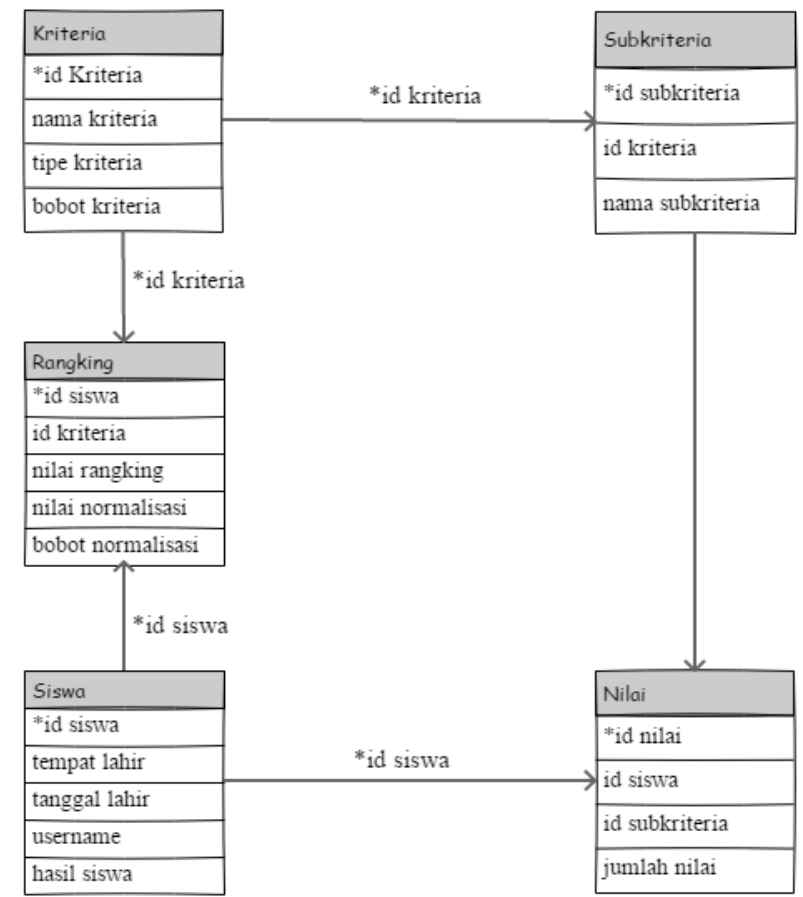

Gambar 4. Rancangan Logical Relational Structure

3. Spesifikasi Basis Data

1) Tabel Login

Nama Tabel : Login

Primary Key : id_login

Tabel 1. Spesifikasi Tabel Login

\begin{tabular}{|c|c|c|c|c|}
\hline$\#$ & Field & Type & Lenght & Keterangan \\
\hline 1 & Id_login & Integer & 255 & Id login \\
\hline 2 & Username & Varchar & 255 & Username \\
\hline 3 & Password & Varchar & 255 & Password \\
\hline
\end{tabular}

2) Tabel Data Siswa

Nama Tabel : Data Siswa

Primary Key : id_siswa

Tabel 2. Spesifikasi Tabel Data Siswa

\begin{tabular}{|c|c|c|c|c|}
\hline$\#$ & Field & Type & Lenght & Keterangan \\
\hline 1 & Id_siswa & Integer & 11 & Id_siswa \\
\hline 2 & $\begin{array}{c}\text { Nama_ } \\
\text { siswa }\end{array}$ & Varchar & 255 & Nama siswa \\
\hline 3 & $\begin{array}{c}\text { Tmpt_lahi } \\
\text { r }\end{array}$ & Varchar & 255 & $\begin{array}{c}\text { Tempat } \\
\text { lahir }\end{array}$ \\
\hline 4 & $\begin{array}{c}\text { Tgl_Lahir } \\
\text { lahir }\end{array}$ \\
\hline 5 & $\begin{array}{c}\text { Alamat_ } \\
\text { siswa }\end{array}$ & Varchar & 255 & $\begin{array}{c}\text { Alamat } \\
\text { siswa }\end{array}$ \\
\hline 6 & username & Varchar & 255 & Username \\
\hline 7 & $\begin{array}{c}\text { Hasil_sis } \\
\text { wa }\end{array}$ & Double & & Hasil siswa \\
\hline
\end{tabular}

3) Tabel Subkriteria

Nama Tabel : Data Subkriteria

Primary Key : id_subkriteria
Tabel 3. Spesifikasi Tabel Data Subkriteria

\begin{tabular}{|c|c|c|c|c|}
\hline$\#$ & Field & Type & Lenght & Keterangan \\
\hline 1 & $\begin{array}{c}\text { Id_ } \\
\text { Subkriteria }\end{array}$ & Integer & 11 & $\begin{array}{c}\text { Id } \\
\text { subkriteria }\end{array}$ \\
\hline 2 & Id_kriteria & integer & 11 & Id kriteria \\
\hline 3 & $\begin{array}{c}\text { Nama_ } \\
\text { Subkriteria }\end{array}$ & varchar & 255 & $\begin{array}{c}\text { Nama } \\
\text { kriteria }\end{array}$ \\
\hline
\end{tabular}

4) Tabel Ranking

Nama Tabel : Ranking

Primary Key : id_siswa, id_kriteria

Tabel 4. Spesifikasi Tabel Hasil Pencarian

\begin{tabular}{|c|c|c|c|c|}
\hline$\#$ & Field & Type & Lenght & Keterangan \\
\hline 1 & Id_siswa & Integer & 11 & Id siswa \\
\hline 2 & Id_kriteria & Integer & 11 & Id kriteria \\
\hline 3 & $\begin{array}{c}\text { Nilai_ } \\
\text { ranking }\end{array}$ & Double & $\begin{array}{c}\text { Nilai } \\
\text { ranking }\end{array}$ \\
\hline 4 & $\begin{array}{c}\text { Nilai_ } \\
\text { normalisasi }\end{array}$ & Double & $\begin{array}{c}\text { Nilai } \\
\text { normalisasi }\end{array}$ \\
\hline 5 & $\begin{array}{c}\text { Bobot_ } \\
\text { normalisasi }\end{array}$ & Double & $\begin{array}{c}\text { Bobot } \\
\text { normalisasi }\end{array}$ \\
\hline
\end{tabular}

\section{PEMBAHASAN}

Untuk mengetahui sejauh mana aplikasi pemilihan siswa terbaik ini dapat menyelesaikan masalah, maka akan dilakukan proses implementasi terhadap aplikasi tersebut. Aplikasi pemilihan siswa terbaik ini dirancang dengan tujuan untuk memudahkan pihak sekolah dalam menentukan pemilihan siswa terbaik secara tepat, cepat, dan akurat.

\subsection{Tampilan Layar Menu Login}

Berikut ini pada gambar 5 adalah tampilan layar dari menu login. Didalam menu login, admin akan diminta untuk memasukan username dan password untuk bisa masuk ke menu Beranda. Jika Admin salah memasukan username atau password, akan muncul pesan gagal login. Jika admin belum memasukan username atau password akan muncul pesan harap isi username atau password.

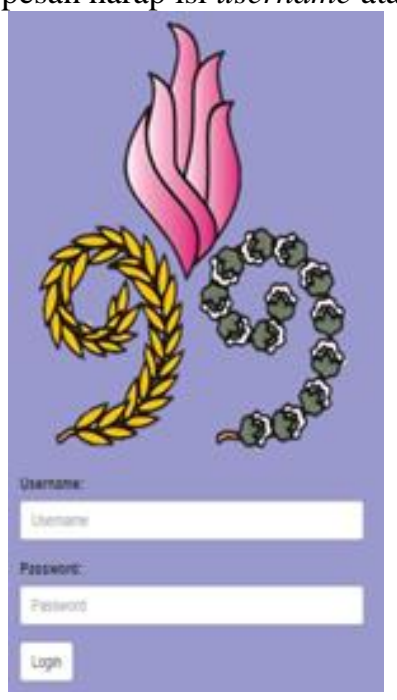

Gambar 5. Tampilan Layar Form Login 


\subsection{Tampilan Layar Menu Beranda}

Berikut ini adalah tampilan layar menu Beranda. Didalam menu beranda terdapat beberapa menu, yaitu menu tambah admin dan menu logout.

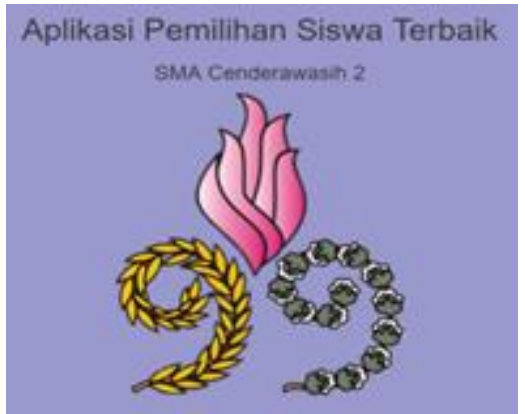

Gambar 8. Tampilan Layar Menu Beranda

\subsection{Tampilan Layar Menu Data Siswa}

Berikut ini pada gambar 9 adalah tampilan layar menu Data Siswa. Di menu data siswa ada beberapa pilihan yaitu tambah data siswa, ubah data siswa atau hapus data siswa. Jika admin ingin menambahkan data siswa, akan diminta untuk menginput nama lengkap, tempat, tanggal lahir, dan alamat siswa. Apabila meng-klik tombol simpan, maka data siswa berhasil disimpan dan datanya akan muncul di sebelah kanan. Jika ada salah satu kolom yang belum terisi, maka akan muncul pesan harap mengisi data tersebut (lihat gambar 10). Jika admin ingin mengubah salah satu data siswa, admin diminta untuk menginput ulang atau merubah data yang sudah diisi, dan apabila diklik tombol simpan akan muncul pesan data berhasil diperbarui. Pada gambar 11, jika admin ingin menghapus salah satu data siswa, akan muncul konfirmasi apakah yakin ingin dihapus atau tidak. Jika memilih tombol OK, maka data siswa berhasil dihapus.

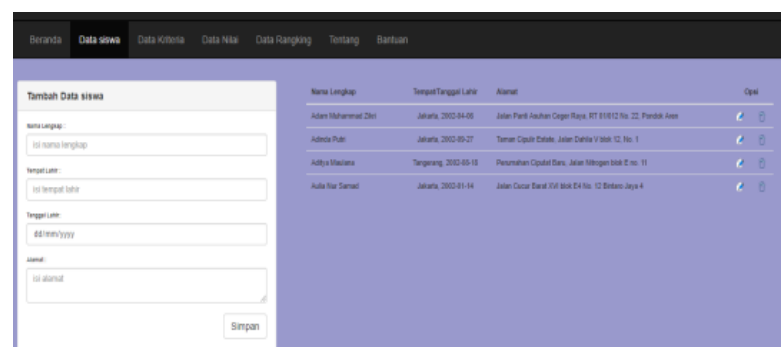

Gambar 9. Tampilan Layar Form Menu Data Siswa

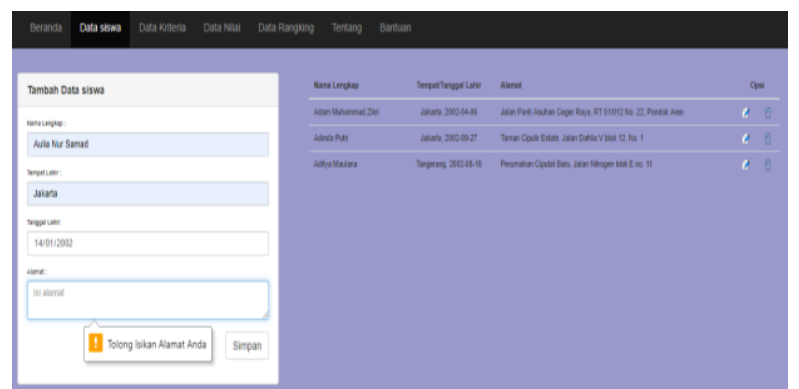

Gambar 10. Tampilan Layar mengubah data siswa

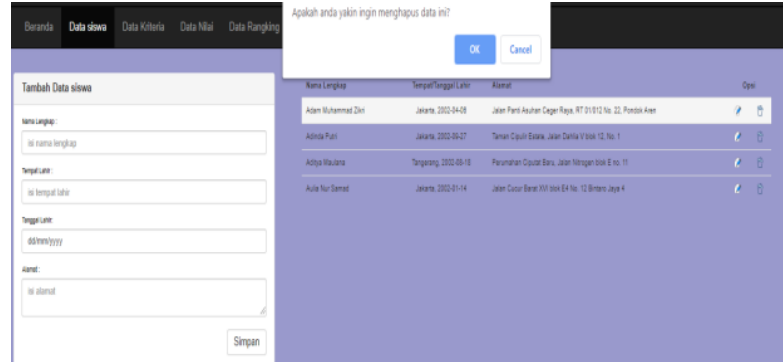

Gambar 11. Tampilan Layar Hapus Data Siswa

\subsection{Tampilan Layar Menu Ranking}

Berikut pad gambar 12 adalah tampilan layar data ranking. Didalam menu data rangking berisi beberapa table nilai yaitu nilai antar siswa per kriteria, nilai siswa yang sudah dinormalisasikan, dan nilai akhir siswa. Jika admin ingin mencetak halaman tersebut, maka klik tombol print lalu akan muncul form sepeyang sesuai dengan isi dari menu data rangking.

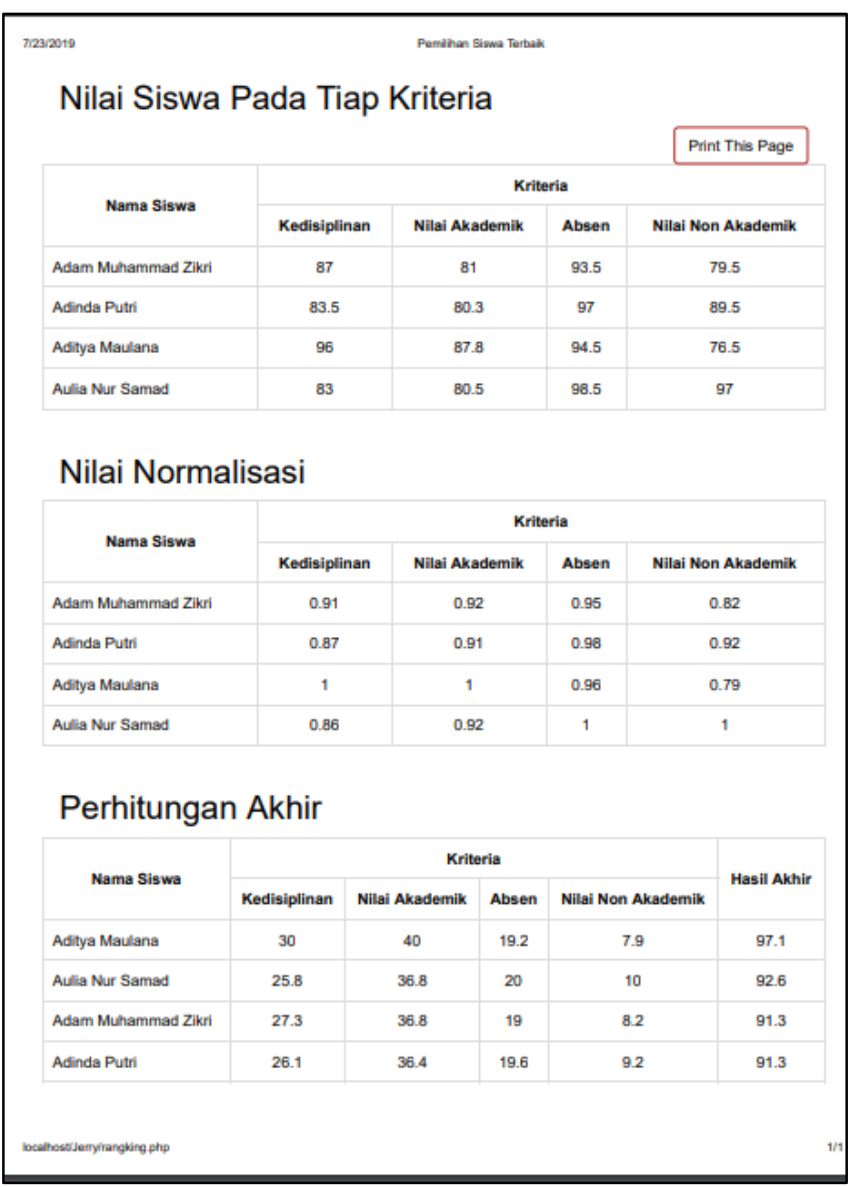

Gambar 12. Tampilan Layar Form Print Data Rankng

\subsection{Evaluasi Program}

Berdasarkan hasil uji program, maka perlu dilakukan evaluasi terhadap program yang telah diuji. Terdapat evaluasi sebagai berikut: 
1. Kelebihan Program

1) Menghasilkan pemilihan siswa terbaik dengan waktu lebih cepat dan sasaran yang akurat.

2) Tidak ada batasan jumlah siswa, kriteria ataupun subkriteria.

2. Kekurangan Program

1) Aplikasi ini tidak bisa menampilkan pemilihan siswa terbaik di tahun sebelumnya.

2) Dalam penginputan data, aplikasi ini masih menggunakan metode manual belum bersifat upload file.

3) Aplikasi pemilihan siswa terbaik ini masih bersifat localhost, belum bersifat online.

\section{KESIMPULAN}

Metode Simple Additive Weighting (SAW) bisa diterapkan dalam sistem pendukung keputusan sehingga dapat memilih siswa terbaik dengan cepat. Aplikasi yang dibangun dapat mempermudah pihak sekolah dalam pemilihan siswa terbaik dengan target yang cepat, akurat, dan obyektif.

Dengan menerapkan sistem komputerisasi dalam pemilihan siswa terbaik ini, sistem pengelolaan data akan semakin tepat dan mengurangi kesalahan dalam perhitungan nilai serta mendapatkan hasil perangkingan yang terbaik.

Dengan menggunakan database, data siswa ataupun data nilai siswa dapat tersimpan didalamnya. Sehingga apabila terjadi kesalahan input data, maka data yang salah dapat langsung diperbaiki tanpa harus menginput ulang semua datanya.

\section{SARAN}

Adanya pengembangan dalam aplikasi sistem pendukung keputusan ini, sehingga tidak perlu menginput data siswa dan data nilai, tetapi admin hanya diminta untuk mengupload file sesuai ketentuan.

Admin diharapkan bisa menerima dan menjalankan aplikasi sistem pendukung keputusan ini, sehingga tidak ada kesalahan dalam proses pemilihan siswa terbaik.

Penggunaan aplikasi sistem pendukung keputusan pemilihan siswa terbaik bisa dikembangkan, sehingga dapat digunakan di sekolah lain.

\section{DAFTAR PUSTAKA}

Atika, Fara dan, Prof. Budi Murtiyasa, M. Kom. 2017. Sistem Pendukung Keputusan Pemilihan Guru Berprestasi Di Kecamatan Kradenan Kabupaten Grobogan Menggunakan Metode Simple Additive Weighting. Diploma thesis, Universitas Muhammadiyah Surakarta.

Elistri, M., Wahyudi, J. and Supardi, R. 2014. Penerapan Metode SAW Dalam Sistem Pendukung Keputusan Pemilihan Jurusan Pada Sekolah Menengah Atas Negeri 8 Seluma, Jurnal Media Infotama Penerapan Metode SAW, 10(2), pp. 1858-2680.
Fitri, N. Y. and Nurhadi. 2017. Analisis dan Perancangan Sistem Pendukung Keputusan Penilaian Kinerja Guru Dengan Menggunakan Metode Simple Additive Weighting (SAW) Pada SMK Yadika Jambi, 2(23023805), pp. 318-326.

Nuril, H and Firdaus, W. 2015. Penilaian Prestasi Kerja Kinerja Pegawai Menggunakan Metode Fuzzy Tsukamoto. 2, pp. 41-48.

Rikki, A., Murni, M., and Jonson, R.2016. Sistem Pendukung Keputusan Penerimaan Karyawan Dengan Metode SAW Pada PT. Karya Sahata Medan, Journal of Informatics Pelita Nusantara, 1(1), pp. 3846.

Sihombing, R., Perdana, A., Solikhun, and Hartama, D. 2016. Sistem Pendukung Keputusan Pemilihan Guru Terbaik pada SMK Maria Goretti Pematangsiantar Menggunakan Metode Simple Additive Weighting (SAW), 1(1).

Situmorang, H. 2015 'Sistem Pendukung Keputusan Pemilihan Calon Peserta Olimpiade Sains Tingkat Kabupaten Langkat Pada Madrasah Aliyah Negeri (Man) 2 Tanjung Pura Dengan Menggunakan Metode Simple Additive Weighting (SAW)', IV(2), pp. 24 30.

Sonata, F. 2016. Implementasi Metode Simple Additive Weighting (SAW) dengan Proses Fuzzifikasi dalam Penilaian Kinerja Dosen. Jurnal Teknologi Informasi dan Komunikasi, 5(2), pp. 71-80

Pratiwi, H. 2016. Buku Ajar Sistem Pendukung Keputusan. Yogyakarta: Deepublish.

Uswatun, N. 2019. Sistem Pendukung Keputusan Pemilihan Karyawan Terbaik Dengan Menggunakan Metode Simple Additive Weighting (Saw) Pada PT Ipro Solusi Canggih Berbasis Web. Jakarta; Novia Uswatun Nur Indahsari.

Utomo, M. 2015. Penerapan Metode SAW Pada Sistem Pendukung Keputusan Untuk Pemberian Beasiswa Pada SMA Negeri 1 Cepu Jawa Tengah. Fakultas Ilmu Komputer Universitas Dian Nuswantoro, Semarang.

Gunawan, G., \& Vidy, V. 2017. Sistem Pendukung Keputusan Pemilihan Kandidat Kepala Divisi Yayasan Airlangga Balikpapan Dengan Metode Simple Additive Weighting. Metik Jurnal, 1(2), 5964. 